\section{The Effect of The Covid-19 Pandemic On The Adaptation Process and Psychiatric Symptoms of Children Aged 7-12: A Telemedicine Study}

\author{
Covid-19 Pandemisi'nin 7-12 Yaş Arası Çocukların \\ Uyum Sürecine ve Psikiyatrik Belirtilerine Etkisi: \\ Bir Teletıp Çalışması
}

Birsen Şentürk Pilan ๑ Serpil Erermiş $\odot$ Reyhan Çalışan ๑ Begüm Yuluğ ๑ Sibel Helin Tokmak $\odot$ Sezen Köse $\odot$ Burcu Özbaran $\odot$ Tezan Bildik $\odot$

\section{ABSTRACT}

Objective: The aim of the presented study is to evaluate the adaptive process and psychiatric symptoms in the 7-12 age group followed-up with telemedicine interviews during the height of the pandemic. Method: Patients between the ages of 7-12 who were followed up in our outpatient clinic were called by telemedicine service at the appointment date. The questionnaire prepared by the researchers in order to investigate the adaptation process to the pandemic was administered, the answers provided by the patients and their families were recorded in the case data form together with Clinical Global Impression (CGI) Scale score appraised by the interviewing psychiatrist. Medical records pertaining to each patient were also reviewed, their psychiatric diagnoses, according to DSM 5 criteria and CGI scores recorded in their last face-to-face interviews during the pandemic period, were included in the case data form. Results: Fifty patients were included in the study. The mean age of the participants was $9.14 \pm 1.61$ years. Attention deficit hyperactivity disorder (60\%) was the most common psychiatric diagnosis detected in the participants before the pandemic, followed closely by anxiety and related disorders (20\%) and specific learning difficulty (16\%). The CGI scores of the cases before, and during the pandemic were $2.72 \pm 0.75$, and $2.92 \pm 0.94$, respectively. The difference between the mean scores was statistically significant $(p=0.024)$. Conclusion: Our study emphasizes the importance of follow-up by telemental health practices in cases where face-to-face psychiatric interviews are not applicable, i.e., due to the risk of transmission of COVID19 disease during the current pandemic.

Keywords: Covid 19-Pandemic, telemedicine, child and adolescent psychiatry, telemental health

\section{öz}

Amaç: Bu çalışmanın amacı, pandeminin yoğun olduğu dönemde, psikiyatrik takipteki 7-12 yaş olguların, teletıp görüşmesi ile uyum süreci ve psikiyatrik belirtilerinin değerlendirilmesidir.

Yöntem: Polikliniğimizde takip edilen 7-12 yaş arası hastalar randevu gün ve saatinde teletıp ile aranmıştır. Pandemiye uyum süreci ile ilgili araştırmacılar tarafından hazırlanan anket uygulanmış, görüşme yapan psikiyatrist tarafından değerlendirilen Klinik Global İzlenim (KGi) Ölçeği puanı ile birlikte vaka veri formuna kaydedilmiştir. Her hastaya ait tıbbi kayıtlar da gözden geçirilmiş, DSM 5'e göre psikiyatrik tanıları ve pandemi döneminden önceki son yüz yüze görüşmelerinde kaydedilen KGi puanları vaka veri formuna dahil edilmiştir.

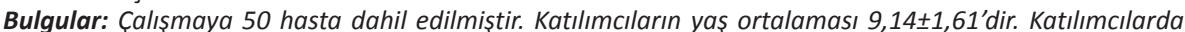
pandemiden önce saptanan psikiyatrik tanılar arasında en yaygın olanı dikkat eksikliği hiperaktivite bozukluğu (\%60) iken, onu anksiyete ve ilişkili bozukluklar (\%20) ve özgül öğrenme güçlüğü (\%16) takip etmiştir. Pandemi öncesi olguların KGi skoru 2,72 $\pm 0,75$, pandemi dönemindeki KGi skoru 2,92 $\pm 0,94$ 'dir. Ortalama puanlar arasındaki fark istatistiksel olarak anlamlıdır $(p=0,024)$.

Sonuç: Çalışmamız, pandemideki bulaş riski nedeniyle yüz yüze psikiyatrik görüşmelerin yapılamadığı psikiyatrik takipteki çocuk ve ergenlerde, Teletıp uygulamaları ile takibin devam edebileceğini ve bunun önemini vurgulamaktadır.

Anahtar kelimeler: Covid 19-Pandemisi, teletıp, çocuk ve ergen psikiyatrisi, telemental sağlık
Received: 12.10 .2020

Accepted: 15.02 .2021

Published Online: 03.08.2021

Cite as: Şentürk Pilan B, ErermişS, Çalışan R, et al. The effect of the Covid-19 pandemic on the adaptation process and psychiatric symptoms of children aged 7-12: A telemedicine study. İzmir Dr. Behçet Uz Çocuk Hast. Dergisi. 2021;11(2):167-73.

Birsen Şentürk Pilan Ege Üniversitesi Çocuk ve Ergen Ruh Sağ lığı ve Hastalıkları Anabilim Dalı İzmir, Türkiye

drbirsensenturk@yahoo.com ORCID: 0000-0002-4580-7655

S. Erermiş 0000-0001-6242-7876

R. Çalışan 0000-0002-3453-2940

B. Yuluğ 0000-0001-7289-4355

S.H. Tokmak 0000-0003-4258-3454

S. Köse 0000-0001-6631-9549

B. Özbaran 0000-0002-4938-4346

T. Bildik 0000-0002-0032-7025 Ege Üniversitesi Çocuk ve Ergen Ruh Sağığı ve Hastalıkları Anabilim Dalı, izmir, Türkiye 


\section{INTRODUCTION}

The members of the large, and diverse Coronaviridae (CoV) family has the capacity to cause a variety of diseases ranging from mild common cold to severe life-threatening infections like Middle East Respiratory Syndrome (MERS) and Severe Acute Respiratory Syndrome (SARS). The novel SARS-CoV-2 can be classified in the latter group, and like all other members of the family, is mainly transmitted by airborne droplets ${ }^{(1)}$. Considering the rate of transmission and global status the novel SARS-CoV-2 and the associated Coronavirus Disease-19 (COVID19) has reached; social distancing, use of personal protective equipment, and personal hygiene have become essential in dealing with the present adverse circumstances.

Studies have advocated that epidemics affecting public health can have an array of psychological effects on the general population, the most common being anxiety, fear, and depressive symptoms ${ }^{(2)}$. The COVID-19 pandemic laid the groundwork for global panic and psychological stress ${ }^{(3)}$. Furthermore, the crisis precipitated by the present epidemic environment may have deleterious effects on the mental health of isolated individuals and those with preexisting mental illnesses (4). The feeling of loneliness that comes with social isolation can adversely affect mental health ${ }^{(5)}$. While the coronavirus pandemic is unquestionably the focus of worldwide attention, the negative psychological, social, and economic effects of the COVID-19 disease deserve utmost consideration for effective management of this extraordinary period ${ }^{(6)}$.

An online study conducted in China during the COVID-19 epidemic reported that 54\% of the 1210 participants had described the mental health impact of the pandemic to be moderate to severe, and the most common disclosed symptoms being depression and anxiety ${ }^{(7)}$. While most studies conducted during this period have focused on the general population and risk groups such as healthcare workers or the elderly, it cannot be denied that the current crisis also presents multifaceted predicaments for children. The epidemic had profound effects on children, youth, and their families necessitating establishment of a new routines and re-planning of daily life ${ }^{(8)}$. Affected family members and loss of relatives during the pandemic period may also cause post-traumatic stress disorder and depression in youth ${ }^{(9)}$.

Children also experience fear, anxiety and uncertainty, physical and social isolation during the COVID-19 epidemic.

The closure of schools and ongoing online education is a novel experience for many children, presenting a tremendous adaptive challenge. The needs of school-age children are essentially the same all over the world regardless of the climate, race, geographical region, and economic development. In a preliminary study conducted in China, it was stated that the most common psychological and behavioral problems among children and adolescents with the COVID-19 pandemic were distractibility, irritability, clinging behavior, and separation anxiety ${ }^{(10)}$.

Undoubtedly, this period will have detrimental effects on the mental health of children, even youth with established protective factors and decent support systems is adversely affected However, this condition also underscores the potential impact of the pandemic on children previously diagnosed with mental health disorders. Children with existing psychiatric diseases are likely to experience difficulties in maintaining their treatment (examination, therapeutic interview, the supply of medicine, etc.) owing to the regulations imposed due to COVID-19 pandemic. Nonetheless, the proliferation of internet services and smartphones, and fifth-generation (5G) mobile networks, which enable mental health professionals and health officials to provide online mental health services during the COVID-19 outbreak are promising innovations. The speedy transmission of the virus prevents conventional face-to-face mental interventions, making online mental health services a safe alternative. To date, various online mental health services have been widely implemented for those in need during the epidemic in China ${ }^{(3)}$.

Within the scope of protective measures at our university, it was deemed appropriate to continue the outpatient services within the framework of 
telemedicine in accordance with the decision of the Coronavirus (COVID-19) Outbreak Coordination Commission dated 18.03.2020. Face-to-face interviews have resumed as of 01.06.2020, but it was decided to continue telemedicine interventions in select cases.

The aim of the presented study is to evaluate the adaptive process and psychiatric symptoms in the 7-12 age group followed-up with telemedicine interventions during the height of the pandemic.

\section{MATERIAL and METHODS}

The present study is designed as a descriptive, cross-sectional research. The children aged 7-12 years who had prior presentations to the child and adolescent psychiatry outpatient clinics and had scheduled for telemedicine follow-ups were included in the study after online written informed consent was provided by the children and their families. According to the telemedicine methodology applied, the patients and their families were interviewed via telephone per decision of the Coronavirus Outbreak Coordination Commission in place of the standard face-to-faceinterviews. Themanagement department of our hospital has integrated the telemedicine methodology into the hospital information system, and the operations of the patients called by telemedicine are performed over the hospital information system. During the study, 65 patients were called by telemedicine services. Fifteen patients could not be reached by phone. Fifty patients and their parents, who could be reached by phone, agreed to participate in the study.

The standard interview framework namely firstly interviewing with the children then their parents was preserved. Psychiatric symptoms were evaluated, followed by the assessment of the functionality of the patient, the effective use of psychotropic medication (if applicable) and then treatment planning. The child and adolescent psychiatrist conducting the tele-interview also provided psychosocial support and guidance to the patients and their families. The allotted time for the complete psychiatric interview was 30-40 minutes, including the administration of the COVID-19 Adaptation Questionnaire prepared by the authors, and the assessment of the patient's global functioning.

The questionnaire prepared by the researchers in order to investigate the adaptation process to the pandemic period was administered, the answers provided by the patients and their families were recorded in the case data form together with the Clinical Global Impression Severity Scale scores appraised by the interviewing psychiatrist. Medical records of each patient were also reviewed, their psychiatric diagnoses, according to DSM 5 criteria and CGI scores recorded during last face-to-face interviews prior to the tele-interview during the pandemic period, were written down in the case data form.

\section{Daignostic tools}

The COVID-19 Adaptation Questionnaire: A structured questionnaire to better record the data disclosed by the patient and their families was prepared by the authors. This brief questionnaire inquired whether there was a health worker at home, whether the patient was affected by the epidemic at home or in his/her immediate environment, the daily routine of the patient and his/her family, exposure to news about the epidemic and changes in sleep patterns and appetite.

Clinical Global Impression Scale (CGI): Clinical Global Impression Scale (CGI) has been utilized as a standardized measurement tool to evaluate the severity of any disease and symptomatic improvement. The evaluation based on this scoring system relies on the clinical judgment of the clinician during the interview. The clinician determines the severity of the disease and the degree of improvement in symptoms on a Likert-type rating scale ranging from 1 to 7 (1-normal, not sick, 2-borderline patient, 3-mildly ill, 4-moderately ill, 5-significantly ill, 6-severely ill, 7-most severely ill) ${ }^{(11)}$.

\section{Ethics Approval}

The present study was submitted to the Ministry of Health in compliance with the national data regarding any scientific research on COVID-19 
disease. The study was subsequently approved and presented to the local medical research ethics committee for ethical approval, and the relevant permission was granted on 10.06.2020 with the decision number: 20-6T/48.

\section{Statistical Analysis:}

Statistical analysis of the data was conducted using the SPSS 25 package program. Sociodemographic characteristics of the patients, complaints at presentation, distribution of psychiatric diagnoses, The COVID-19 Adaptation Questionnaire, and CGI scores were evaluated by descriptive statistical analysis methods, and frequency analysis. Paired samples Student's t-test was employed to infer the differences in CGI scores before and after the pandemic. The $p$-values less than 0.05 were considered statistically significant for all analyses.

\section{RESULTS}

Sixteen (32\%) female, and 34 (68\%) male patients were included in the study. The mean age of the participants was $9.14 \pm 1.61$ years, and a significant number $(n=38 ; 76 \%)$ of the participants were living

Table 1. Sociodemographic data.

\begin{tabular}{|c|c|}
\hline & $\begin{array}{c}\text { Completed psychiatric } \\
\text { interviews } \\
n=50\end{array}$ \\
\hline \multicolumn{2}{|l|}{ Age, m, (std) } \\
\hline Male & $9.14 \pm 1.61$ \\
\hline Female & $9.26 \pm 1.46$ \\
\hline Gender, n (\%) & $8.87 \pm 1.92$ \\
\hline \multicolumn{2}{|l|}{ Male } \\
\hline Female & $34(68)$ \\
\hline Family Structure, n (\%) & $16(32)$ \\
\hline \multicolumn{2}{|l|}{ Nuclear family } \\
\hline Broken family & $38(76)$ \\
\hline Extended family & $5(10)$ \\
\hline Foster family & $6(12)$ \\
\hline Healthcare Provider Present in Immediate & $1(2)$ \\
\hline \multicolumn{2}{|l|}{ Environment, n (\%) } \\
\hline Yes & $10(20)$ \\
\hline No & $39(78)$ \\
\hline \multicolumn{2}{|l|}{ Relatives Affected by the Outbreak, n (\%) } \\
\hline Affected & $3(6)$ \\
\hline Unaffected & $47(94)$ \\
\hline
\end{tabular}

with a nuclear family. Twenty percent $(n=10)$ of the patients participating in the study indicated that they were living with a healthcare professional at home. Patients with relatives affected by the epidemic in their immediate surroundings constituted $6 \%(n=3)$ of the participants in the study. Sociodemographic data of the patients are summarized in Table 1.

During lockdown period, the study participants spent their times reading books ( $n=10 ; 20 \%$ ), playing video games ( $n=27 ; 54 \%)$, watching television or other streaming services $(n=33 ; 66 \%)$, in social media applications ( $n=33 ; 66 \%)$, studying ( $n=42 ; 84 \%)$, participating in various leisure activities such as drawing, painting, gardening, playing an instrument etc., $(n=8 ; 16 \%)$ and $6 \%(n=3)$ exercising $(n=3 ; 6 \%)$. Compared to the pre-pandemic period sleep patterns of $50 \%(n=25)$ of the participants deviated from the baseline. The remaining $50 \% \quad(n=25)$ of the participants, however, reported no change in their sleep patterns. Concerning the nutritional status of the participants during the pandemic period, an increase in appetite was reported in $28 \%(n=14)$, and a decrease in $12 \%(n=6)$ of the patients. An irregularity in mealtimes and portions was reported by $2 \%(n=1)$ of the participants, while $58 \%(n=29)$ of the cases

Table 2. Preferred pastime activities and changes in sleep and appetite during the pandemic.

\begin{tabular}{lc}
\hline & $\begin{array}{c}\text { Completed psychiatric } \\
\text { interviews } \\
\mathbf{n}=50\end{array}$ \\
\hline Preferred Pastime Activities, $\mathrm{n}(\%)$ & $10(20)$ \\
$\quad$ Reading & $27(54)$ \\
Video games & $33(66)$ \\
Television/streaming services & $33(66)$ \\
Social media & $42(84)$ \\
Educational activities & $3(6)$ \\
Physical activities & $8(16)$ \\
Other leisure activities & \\
Sleep & $25(50)$ \\
Disruption & $25(50)$ \\
No disruption & $14(28)$ \\
Appetite & $6(12)$ \\
Increased & $1(2)$ \\
Decreased & $29(58)$ \\
Disruption in feeding pattern & \\
No difference & \\
\hline Numbers and percentages are calculated separately for each \\
activity
\end{tabular}


reported no change in their dietary habits or appetites. A summary of the changes reported by the patients in relation to the pandemic period is presented in Table 2.

While $60 \%(n=30)$ of the study participants disclosed that they stayed up-to-date on pandemic related news, 20 (40\%) participants said that they had not read, and listen the news about COVID-19 disease. Thirty percent $(n=15)$ of the patients who regularly listened or read COVID-19-related news stated that exposure to pandemic-related media had a moderate impact on their overall wellbeing. While $2 \%(n=1)$ of them reported that they were being severely, and $16 \%(n=8)$ mildly affected by the news. about COVID-19 outbreak. Seventy-eight percent of the participants in the study stated that they spent time with their families and took part in various activities during the day.

Attention deficit hyperactivity disorder (60\%) was the most frequently encountered disease among the psychiatric diagnoses detected before the pandemic in the participants, followed closely by anxiety and related disorders (20\%) and specific learning difficulty (16\%). Frequencies of the other diagnostic categories are summarized in Table 3.

Table 3. Psychiatric diagnoses of the participants according to DSM-5.

\begin{tabular}{lc}
\hline & $\begin{array}{c}\text { Completed psychiatric } \\
\text { interviews } \\
\mathbf{n}=\mathbf{5 0}\end{array}$ \\
\hline Psychiatric Diagnoses, $\mathrm{n}(\%)$ & \\
Attention Deficit Hyperactivity Disorder & $30(60)$ \\
Anxiety and Related Disorders & $10(20)$ \\
Specific Learning Difficulty & $27(54)$ \\
Mild Intellectual Disability & $33(66)$ \\
Communication Disorders & $33(66)$ \\
Tic Disorders & $42(84)$ \\
Post Traumatic Stress Disorder & $3(6)$ \\
Psychosis & $8(16)$ \\
\hline
\end{tabular}

Numbers and percentages are calculated separately for each activity accounting for comorbid diagnoses.

No difference was disclosed in the severity or the frequency of existing psychiatric complaints in 56\% $(n=28)$ of the participants. While $11(22 \%)$ study participants reported an increase, and $6(12 \%)$ of them stated a decrease in the severity or the frequency of their existing psychiatric symptoms . However, $10 \%(n=5)$ of the participants indicated alterations in their existing symptoms as increased irritability $(n=4 ; 8 \%)$, decreased sleep time $(n=2 ; 4 \%)$, increased anxiety $(n=13 ; 26 \%)(n=13)$ increased anxiety, increased appetite $(n=1 ; 2 \%)$ and an increase in activity $(n=3 ; 6 \%)$.

Postliminary review of the patients' medical records revealed that selective serotonin reuptake inhibitors (SSRIs) ( $n=4 ; 8 \%$ ), antipsychotics ( $n=2 ; 2 \%)$, stimulants $(n=6 ; 28 \%)$, benzodiazepines $(n=1 ; 2 \%)$ antipsychotics and SSRIs ( $n=2 ; 4 \%)$, antipsychotics and stimulants $(n=3 ; 6 \%)$ were used by indicated number of the participants. Forty-four percent $(n=22)$ of the cases disclosed that they were not prescribed any psychotropic medication. The mean CGI scores of the cases before, and during the pandemic were $2.72 \pm 0.75$, and $2.92 \pm 0.94$, respectively. The difference between the mean CGI scores was statistically significant $(p=0.024)$.

When the participants were inquired concerning the activities they would prefer to do if they had the opportunity, going outside ( $n=12 ; 24 \%)$, spending time with friends ( $n=11 ; 22 \%)$, going to school $(n=5$; $10 \%)$, going to school and seeing friends $(n=4 ; 8 \%)$, and "stopping the pandemic," were expressed by respective number of patients, while $4 \%(n=2)$ of the participants did not specify any activities.

\section{DISCUSSION}

It is clear that pandemic will have negative effects on children, irrespective of the presence of a a psychiatric diagnosis ${ }^{(12)}$. The closure of schools has disrupted both the social and academic lives of children and youth, contributing to the difficulty in maintaining healthy communication with their peers. Prolonged absence from school, being away from friends and teachers, being insufficiently informed about the pandemic or overexposure to pandemic related news, lack of personal space during the lockdown, and the economic burden of the epidemic adversely affected the mental health of children and young people ${ }^{(13)}$.

Studies have indicated that an increase in fear 
and anxiety, restlessness, difficulty focusing, refraining from fulfilling responsibilities, and sleep problems are among the reported emotional and behavioral adverse effects for school-age children (14). In our study, in accordance with the literature, it was determined that there were changes in sleep patterns in $50 \%$ of our participants. Parallel to the established literature during the COVID-19 pandemic, during the lockdown period we noticed increased nervousness in $8 \%(n=4)$, increased anxiety in $26 \%$ $(n=13)$, and increased levels of activity in $6 \%(n=3)$ of our patients. However, $39.2 \%$ of the participants $(n=20)$ reported no change in their current psychiatric complaints.

It has been clearly demonstrated that the epidemic affects the mental health of both children and parents, but it has been also stated that the psychiatric dimension of the epidemic is very pronounced in people with psychiatric diseases ${ }^{(15)}$. When the psychiatric symptoms of the cases before and after the pandemic were compared, it was reported that the number of symptoms increased in $22 \%(n=11)$, decreased in $12 \%(n=6)$, and did not change in $10 \%(n=5)$ of the patients. The mean CGI scores of the cases before, and during the pandemic were $2.72 \pm 0.75$, and $2.92 \pm 0.94$, respectively with a statistically significant difference in support of the existing literature.

In a study conducted in Shanghai, China with a group of children and adolescents aged 6-17 years, a significant decrease in physical activity together with an increase in screen exposure during the epidemic was recorded. The role of physical activity in maintaining both the physical and mental health of children is well established ${ }^{(16)}$. In addition, the feelings of loneliness brought about by social isolation can adversely affect mental health ${ }^{(6)}$. Both a decrease in physical activity and an increase in perceived loneliness due to limited communication with peers would severely disrupt the daily routines of children and youth. However, these disruptions would affect children with ADHD more profoundly. Considering that the most common diagnosis in our sample was ADHD, an increase in our participants' reported symptoms might have been aggravated by the aforementioned factors.

A study in China reported that media entertainment, reading books, and physical exercise were successfully utilized by families to alleviate their children's distress and to relieve their worries about the unfavourable circumstances they experienced ${ }^{(17)}$. In our study, it was observed that most of the participants spent time playing games on the computer $(54 \%)$ or social media $(66 \%)$, while fewer participants spent time reading books (20\%) or exercising (6\%).

Our literature review revealed few studies on the psychiatric follow-up of the 7-12 age group during the pandemic period. During the pandemic, the mental health of both families and children, their sleep pattern, nutrition, and daily routines were adversely affected. Patients with mental disorders or disabilities require regular psychotherapy and psychiatric treatment. Therefore, the lack of access to healthcare services can adversely impact children and youth with mental health disorders due to delays in both diagnosis and treatment ${ }^{(18)}$.

\section{CONCLUSION}

Our study emphasizes the importance of followup by telemental health practices in cases where face-to-face psychiatric interviews are not applicable due to the risk of transmission of COVID-19 disease in the current pandemic. The present study was conducted in the early stages of the pandemic; therefore, it would be appropriate to reevaluate the same group in later stages to assess for comorbid psychiatric diagnoses wrought on by the pandemic and associated social distancing, isolation, and lockdown practices. Since the closure of schools resulted in diminished social activities and less time spent with peer groups for children, while increasing time spent with parents resulting in parental fatigue, establishing multidisciplinary support groups and providing parental guidance would be blessing practices during these trying times. Furthermore, implementing and cultivating telemedicine as an evidence-based practice would also prove beneficial as a viable alternative to in-person psychiatric 
B. Şentürk Pilan et al. The Effect of The Covid-19 Pandemic On The Adaptation Process and Psychiatric Symptoms of Children Aged 7-12: A Telemedicine Study

interviews to prevent interruptions in the psychiatric care of children and youth.

\section{Limitations}

Patients aged between 7-12 years are accepted to our specialized polyclinics in The Child and Adolescent Mental Health Department of our university. However, the fact that preschool and adolescent groups were not included in our study constituted a limitation of our study.

Another limitation of the study is that the CGI scores before the pandemic were calculated retrospectively based on file information.

\section{Acknowledgement}

We thank İpek İnal Kaleli for her assistance with the English translation.

Ethics Committee Approval: Ege University Medical Research Ethics Committee approval was obtained (10.06.2020/20-6T/48).

Conflict of Interest: The authors declared that there were no conflict of interest.

Funding: Used no funding resource.

Informed Consent: Online written informed consent was provided by the children and their families.

\section{REFERENCES}

1. Scientific Committee Study COVID-19 (SARS-Cov-2 Infection) Guidelines.

2. Cao W, Fang Z, Hou G, Han M, Xu X, Dong J et al. The psychological impact of the COVID-19 epidemic on college students in China. Psychiatry Res. 2020;287:112934. https://doi.org/10.1016/j.psychres.2020.112934

3. Liu S, Yang L, Zhang C, Siang YT, Liu Z, Hu S et al. Online mental health services in China during the COVID-19 outbreak. Lancet Psychiatry. 2020;7(4):e17-e8. https://doi.org/10.1016/S2215-0366(20)30077-8

4. Yahya AS, Khawaja S, Chukwuma J. The Impact of COVID-19 in Psychiatry. Prim Care Companion CNS Disord. 2020;22(2). https://doi.org/10.4088/PCC.20102627

5. Armitage R, Nellumus LB. COVID-19 and the consequences of isolating the elderly. Lancet Public Health. 2020;5(5):e256. https://doi.org/10.1016/S2468-2667(20)30061-X

6. Osi K, Popovi S, Sarlija M, Kesedzi I. Impact of Human Disasters and COVID-19 Pandemic on Mental Health: Potential of Digital Psychiatry. Psychiatr Danub. 2020;32:25. https://doi.org/10.24869/psyd.2020.25
7. Wang C, Pan R, Wan X, Tan Y, Xu L, Ho CS et al. Immediate Psychological Responses and Associated Factors during the Initial Stage of the 2019 Coronavirus Disease (COVID-19) Epidemic among the General Population in China. Int. J. Environ. Res. Public Health. 2020;17:1729. https://doi.org/10.3390/ijerph17051729

8. Fegert JM, Vitiello B, Plener PL, Clemens V. Challenges and burden of the Coronavirus 2019 (COVID-19) pandemic for child and adolescent mental health: A narrative review to highlight clinical and research needs in the acute phase and the long return to normality. Child and Adolescent Psychiatry and Mental Health vol. 14 (2020). https://doi.org/10.1186/s13034-020-00329-3

9. Stikkelbroek Y, Bodden DHM, Reitz E, Vollebergh WAM, Van Baar AL. Mental health of adolescents before and after the death of a parent or sibling. Eur. Child Adolesc. Psychiatry. 2016;25:49-59. https://doi.org/10.1007/s00787-015-0695-3

10. Jiao WY, Wang LN, Liu J, Fang SF, Jiao FY, Pettoello-Mantovani $\mathrm{M}$, et al. Behavioral and emotional disorders in children during the COVID-19 epidemic. J Pediatr. 2020;221:264-6. e1. https://doi.org/10.1016/j.jpeds.2020.03.013

11. Guy W. Clinical Global Impressions. ECDEU Assessment Manual for Psychopharmacology Revised. 1976 Rockville, MD: U.S. Department of Health, Education, and Welfare; Public Health Service, Alcohol; Drug Abuse, and Mental Health Administration; National Institute of Mental Health. pp. 218-222.

12. Şahbudak B, Inal Emiroğlu N. COVID-19 Pandemic and Mood Disorders in Children and Adolescents. Turk J Child Adolesc Ment Health. 2020;27(2):59-63.

https://doi.org/10.4274/tjcamh.galenos.2020.55265

13. The psychological impact of quarantine and how to reduce it: Rapid review of the evidence/ National Collaborating Centre for Determinants of Health. Accessed August 30, 2020. https://nccdh.ca/resources/entry/the-psychologicalimpact-of-quarantine-and-how-to-reduce-it-rapid-review-of.

14. Imran N, Zeshan M, Pervaiz Z. Mental health considerations for children \& adolescents in COVID-19 pandemic. Pak J Med Sci. 2020;36(COVID19-S4). https://doi.org/10.12669/pjms.36.COVID19-S4.2759

15. Moreno C, Wykes T, Galderisi S, Nordentof M, Crossley N, Cannon $\mathrm{M}$ et al. How mental health care should change as a consequence of the COVID-19 pandemic. Lancet Psychiatry. 2020;7(9):813-24.

https://doi.org/10.1016/S2215-0366(20)30307-2

16. Impact of COVID-19 pandemic on children and adolescents' lifestyle behavior larger thanexpected. AccessedAugust30,2020.https://www.ncbi.nlm.nih.gov/ pmc/articles/PMC7190470/

17. Jiao WY, Wang LN, Liu J, Fang SF, Jiao FY, Pettoello-Mantovani $\mathrm{M}$, et al. Behavioral and Emotional Disorders in Children during the COVID-19 Epidemic. The J al of Pediatrics. 2020. https://doi.org/10.1016/j.jpeds.2020.03.013

18. Challenges and burden of the Coronavirus 2019 (COVID-19) pandemic for child and adolescent mental health: a narrative review to highlight clinical and research needs in the acute phase and the long return to normality. Accessed August 30, 2020. https://www.ncbi.nlm.nih.gov/pmc/articles/ PMC7216870/ 